\title{
Electronic Waste Generation Prediction in Bandung City, Indonesia
}

\author{
I Made Wahyu WIDYARSANA ${ }^{1 *}$, Dewi Suryanindah SUPRAMONO², Nabil FADEL ${ }^{3}$ \\ ${ }^{1-3}$ Bandung Institute of Technology, Jl. Ganesa No.10, Lb. Siliwangi, Kecamatan Coblong, Kota Bandung, \\ Jawa Barat 40132, Indonesia
}

\begin{abstract}
Nowadays waste electrical and electronic equipment (WEEE) generation is increasing due to the increase in the number of users and the development of electronic products. In Indonesia, there are no specific regulations about WEEE even though it is identified as hazardous and toxic waste. This study aims to predict the WEEE generation from the most used and replaced electronic products by citizens of Bandung City. The data is collected by surveying $\mathbf{4 0 0}$ families in Bandung City. Based on the survey results, there are three types of electronic products that are most used and replaced by citizens of Bandung City, which are mobile phones, laptops and televisions. The Delay Model is modified by replacing the lifespan variable with end-of-life to project the mobile phones, laptops and televisions waste generation in Bandung City. The purpose of this modification is to adjust the pattern of electronic products used in developing countries. The projection results state that Bandung City will generate 0.61 tons/day of mobile phones, 8.66 tons/day of laptops and 3.16 tons/day of televisions at the end of 2020 . Based on the results of the projection, WEEE management and recycling is important which can reduce WEEE disposal and increase the economic value of WEEE.
\end{abstract}

Keywords - Delay model; dropbox; electronic waste generation; electronic waste recycling; waste electrical; electronic equipment

\section{INTRODUCTION}

The growth of the electronics industry continues to increase along with the increasing consumer demand. It is not uncommon to purchase electronic products to replace products that are already owned, but the quality is worse or in a damaged condition. For example, every year, new mobile phones and laptop products emerge that have better features. Besides, there is a change of monitors from the tube model to a flat screen. The unused product then becomes waste electrical and electronic equipment (WEEE). Not only from the consumer side, the electronics industry itself produces WEEE from reject goods. This has caused the WEEE generation continues to increase. WEEE is hazardous and toxic material waste [1].

Indonesia is a developing country where the $3 \mathrm{R}$ concept is common. Developing countries generally have low economic factors, supportive social life, a growing informal sector, and policies that have no restrictions. People with lower middle economic levels tend to repair their e-products when it damaged rather than buying new products. Meanwhile, people with a middle to upper economic level tend to give their used e-products to their families, closest friends, and other parties who have social relations with them. That causes the end-of-life e-

* Corresponding author.

E-mail address: imww.research@gmail.com 
products to belong. The existence of the informal sector that conducts e-product repairs also contributes to the same thing [2].

There are still many WEEE that has not been well managed yet. It can threaten human health and the environment. WEEE producers who do not manage their waste well are still not aware of the importance of protecting the environment. This can be caused by the management of the waste which requires cost, knowledge, and licensing. However, according to Government Regulation No.101 of 2014 about Management of Hazardous and Toxic Waste, waste producers who cannot collect, transport, recycle, and process WEEE, can be submitted to third parties who have permits.

In Indonesia, there are no regulations that specifically regulated WEEE. Also, data on the number of electronic product production, imports, generation of WEEE, and their life cycle data in Indonesia is not yet available. To formulate this policy concept, comprehensive research is needed, including data on the handling of existing WEEE up to inventory material flow analysis and projections of the generation of WEEE and material flow in the future. This study aims to predict the generation of WEEE on a city scale in Indonesia by adjusting the eproduct usage patterns in developing countries.

\section{WEEE MaNagement IN BANDUng City}

Bandung City is located in the West Java region and is the capital of West Java Province. The total area of Bandung City is $167.31 \mathrm{~km}^{2}$ which is divided into 30 sub-districts covering 151 urban villages. The largest district is Gedebage and the smallest is Astanaanyar [3].

WEEE management in Indonesia, especially in the city of Bandung, has not been carried out systematically because regulations related to WEEE are not specific in regulating WEEE waste management. In Indonesia, there is no segregation and organized collection of household electronic waste [4]. Based on the results of a survey of 400 households in Bandung, as many as $98.8 \%$ of respondents did not know how to manage the WEEE they generated. Percentage of respondents' treatment of mobile phones, laptops and televisions waste can be seen in Fig. 1.

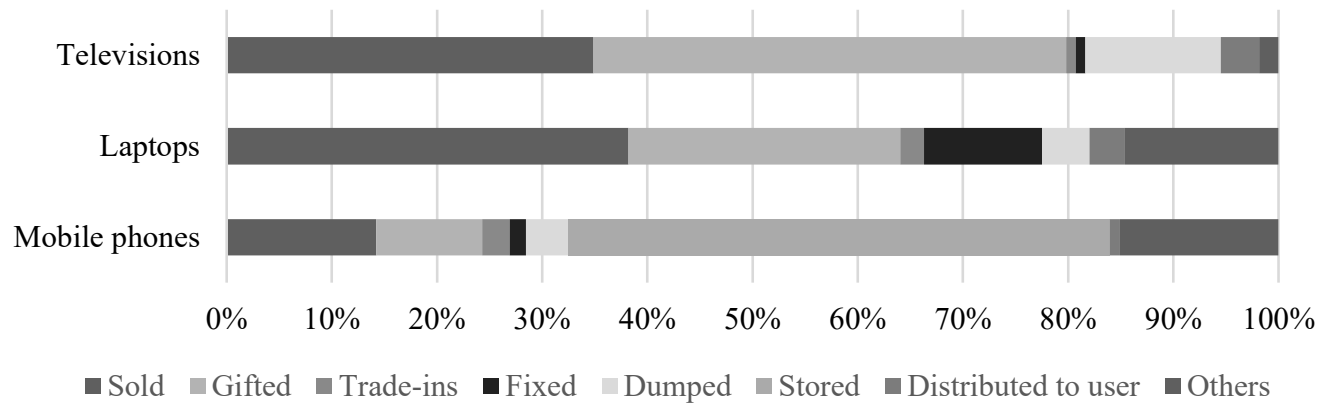

Fig. 1. Percentage of treatment of mobile phones, laptops and televisions waste in Bandung City.

\section{Materials ANd Methods}

\subsection{Scopes and System Boundary}

This research was conducted in Bandung City with WEEE generated by the people of Bandung City as the object of research. To find out the generation of WEEE was carried out 
sampling with survey methods. The number of samples is determined by the number of households in the city of Bandung in 2019. The number of households is determined through projections using an exponential method from the data of the population of the city of Bandung from 2006-2015 [5] with the assumption that one family consists of four people. The graph of population growth projection results can be seen in Fig. 2.

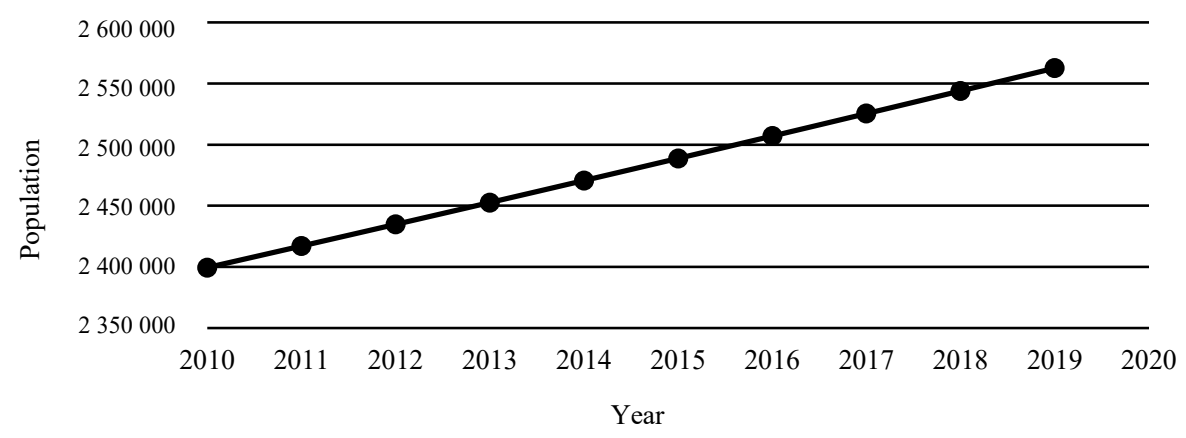

Fig. 2. Graph of the results of the population growth projection for the city of Bandung until 2019.

In this research, the target confidence level of the expected sample is $95 \%$. For this reason, using the [6], an error value of $5 \%$ was set. An error of $5 \%$ can be achieved if the specified sample is 400 families from 640.655 families in Bandung City on 2019.

$$
n=\frac{N}{1+\left(N \cdot e^{2}\right)},
$$

where

$N \quad$ total population;

e error;

$n \quad$ total sample, resulting $n=400$ households.

The electronic products studied are mobile phones, laptops, and televisions. The three products were selected through a preliminary survey conducted in December 2018. Preliminary survey results indicate that mobile phones, laptops, and televisions are electronic products that are most often replaced by the citizens of Bandung. The graph of the survey results is shown in Fig. 3.

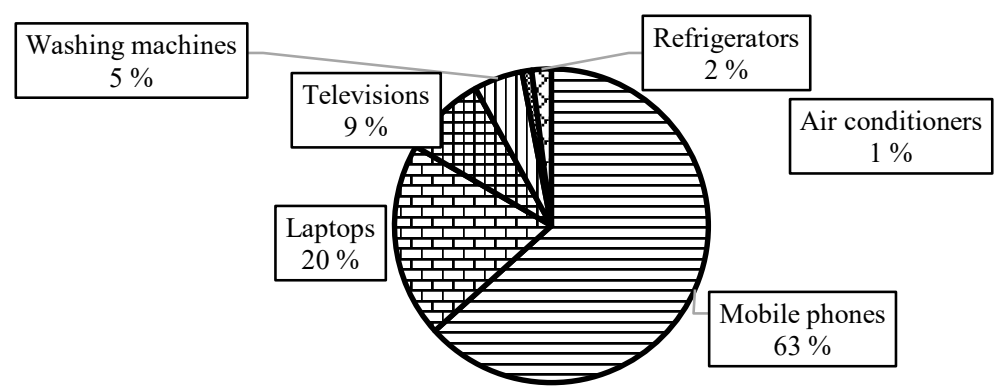

Fig. 3. Preliminary survey results related to electronic products that are the most often replaced by the citizens of Bandung. 


\subsection{Data Collection Methods}

The data collection method for WEEE generation is done by survey and interview. The survey was conducted by distributing questionnaires offline and online. Before the main survey of data collection of WEEE generation, a preliminary survey was conducted to collect data on the number of e-products owned and replaced by the citizens of Bandung. The eproducts includes that are still used or not used but are still stored. The results of the preliminary survey showed that the three most electronic products owned by citizens of Bandung and were frequently replaced were mobile phones, laptops, and televisions. These three electronic products will be managed and projected.

The main survey questionnaire content is about the ownership of mobile phones, laptops, and televisions which include the current conditions, the initial conditions when purchased, the year of purchase, the year when the e-product is not used, and the treatment of e-products after being unused.

\subsection{Projection Calculation}

The projection of mobile phones, laptops and televisions waste generation using The Delay Model method. The Delay Model applied is modified by changing the Lifespan variable with End-of-Life so that it will adjust the treatment of the citizens of Bandung to WEEE. This method has a fairly high accuracy and involves EoL so that the projection results are more representative. Also, the need for data to make projections with this method is following the availability of data in Bandung. In the concept of projected electronic waste generation, waste generation in a year (outflow) is a purchase (inflow) in a year which is the difference from the year of generation projected by end of life [7].

In this study, the value of end-of-life (EoL) is obtained from the calculation of the average length of the e-products from the condition of being used to not being used. There are 2 types of EoL values, namely Extended and Non-Extended. Extended EoL is defined as EoL with an extended usage period, for example e-products that are sold, given, exchanged, and repaired so that their life longer. Non-Extended EoL is defined as EoL without an extension of usage time, for example e-products that are discarded, stored, distributed to the recycler, and experience other conditions, such as lost or stolen. Based on the survey results, the value of mobile phones' extended EoL is 5 years and the non-extended EoL value is 3 years. In Table 1, it can be seen the percentage of extended EoL and Non-Extended EoL obtained from data on the treatment of mobile phones, laptops, and televisions in 1999 to 2018 obtained through household sector surveys.

TABle 1. Percentages of EXTENDED EOL AND NON-EXTENDED EOL OBTAINED FROM TREATMENT DATA ON MOBILE PHONES, LAPTOPS AND TELEVISIONS

\begin{tabular}{|c|c|c|c|c|c|c|c|c|c|c|}
\hline \multirow{2}{*}{ Treatment } & & \multicolumn{3}{|c|}{ Mobile phones } & \multicolumn{3}{|l|}{ Laptops } & \multicolumn{3}{|c|}{ Televisions } \\
\hline & & Quantity & & EoL & Quantity & & EoL & Quantity & & EoL \\
\hline \multirow{4}{*}{ Extended } & Sold & 119 & \multirow{4}{*}{$28 \%$} & \multirow{4}{*}{$\begin{array}{l}5 \\
\text { years }\end{array}$} & 34 & \multirow{4}{*}{$31 \%$} & \multirow{4}{*}{$\begin{array}{l}7 \\
\text { years }\end{array}$} & 38 & \multirow{4}{*}{$43 \%$} & \multirow{4}{*}{15 years } \\
\hline & Given & 84 & & & 23 & & & 49 & & \\
\hline & Trade-in & 22 & & & 2 & & & 1 & & \\
\hline & Repaired & 13 & & & 10 & & & 1 & & \\
\hline \multirow{2}{*}{$\begin{array}{l}\text { Non- } \\
\text { Extended }\end{array}$} & Discarded & 34 & \multirow{2}{*}{$72 \%$} & \multirow{2}{*}{$\begin{array}{l}3 \\
\text { years }\end{array}$} & 4 & \multirow{2}{*}{$69 \%$} & \multirow{2}{*}{$\begin{array}{l}4 \\
\text { years }\end{array}$} & 14 & \multirow{2}{*}{$57 \%$} & \multirow{2}{*}{8 years } \\
\hline & Stored & 430 & & & 131 & & & 100 & & \\
\hline
\end{tabular}




\begin{tabular}{|c|c|c|c|c|c|c|c|}
\hline \multirow{4}{*}{ Treatment } & & \multicolumn{2}{|c|}{ Mobile phones } & \multicolumn{2}{|l|}{ Laptops } & \multicolumn{2}{|c|}{ Televisions } \\
\hline & & Quantity & EoL & Quantity & EoL & Quantity & EoL \\
\hline & $\begin{array}{l}\text { Distributed } \\
\text { to Recycler }\end{array}$ & 8 & & 2 & & 4 & \\
\hline & Others & 126 & & 13 & & 2 & \\
\hline
\end{tabular}

\section{Result}

To make a projection of mobile phones, laptops and televisions waste generations with a modified delay model, inflow data (purchases) for 2020 will be reduced by EoL for each type of unit. For example, for the projection of extended laptop waste generation in 2020, inflow data is needed in 2015 and non-extended data in 2017. The inflow data is obtained from survey results that produce relevant inflow data from 1999 to 2018 so there is no need to project inflow data for the projected generation of waste in 2020. Data from 1989-1998 are considered to be under-representative due to a lack of availability of product ownership data. This happened because the average respondent could not remember their respective mobile phones ownership from 1989 to 1998 . Then, the data in 2019 were considered to be less representative because there was no data until the end of 2019, considering the survey was conducted from January to March 2019. The results of the projected generation of mobile phones, laptops and televisions waste are listed in Table 2.

\section{TABle 2. Results of the Projection of Mobile PhONES, LAPTOPS AND TELEVISIONS WASTE GENERATION IN BANDUNG}

\begin{tabular}{|c|c|c|c|c|c|c|c|c|c|c|}
\hline & & & 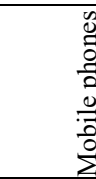 & & & $\begin{array}{l}\text { 今े } \\
\text { 总 } \\
\text { ज्ञ }\end{array}$ & & & $\begin{array}{l}0 \\
0 \\
0 \\
0 \\
\frac{0}{0} \\
0 \\
\end{array}$ & \\
\hline$\underset{\nu}{\vec{\nexists}}$ & 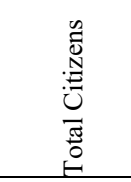 & 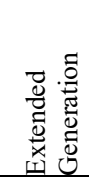 & 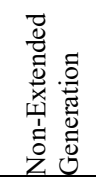 & 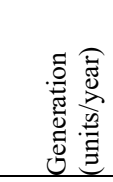 & 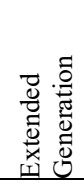 & 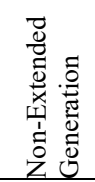 & 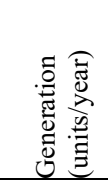 & 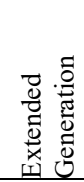 & 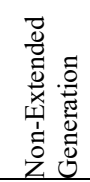 & 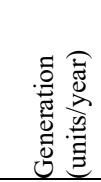 \\
\hline 1999 & 2214097 & 0 & 0 & 0 & 0 & 0 & 0 & 0 & 0 & 0 \\
\hline 2000 & 2230339 & 0 & 0 & 0 & 0 & 0 & 0 & 0 & 0 & 0 \\
\hline 2001 & 2246700 & 0 & 1 & 4.018 & 0 & 0 & 0 & 0 & 2 & 9.675 \\
\hline 2002 & 2263181 & 0 & 2 & 12.142 & 0 & 0 & 0 & 0 & 4 & 22.740 \\
\hline 2003 & 2279783 & 0 & 0 & 1.623 & 0 & 0 & 0 & 0 & 3 & 16.362 \\
\hline 2004 & 2296506 & 1 & 3 & 21.331 & 0 & 1 & 7.881 & 0 & 3 & 16.482 \\
\hline 2005 & 2313353 & 0 & 4 & 20.685 & 0 & 0 & 0 & 4 & 3 & 41.231 \\
\hline 2006 & 2330322 & 1 & 9 & 60.809 & 0 & 1 & 7.997 & 0 & 3 & 19.206 \\
\hline 2007 & 2347417 & 1 & 10 & 67.123 & 1 & 1 & 7.709 & 0 & 20 & 114.563 \\
\hline 2008 & 2364636 & 4 & 10 & 81.079 & 0 & 1 & 8.115 & 0 & 3 & 20.365 \\
\hline 2009 & 2381982 & 4 & 21 & 151.524 & 1 & 1 & 11.910 & 1 & 7 & 48.637 \\
\hline 2010 & 2399456 & 4 & 28 & 191.253 & 0 & 4 & 26.585 & 3 & 6 & 55.767 \\
\hline
\end{tabular}




\begin{tabular}{lllllllllll}
\hline 2011 & 2417057 & 9 & 42 & 306.628 & 1 & 9 & 57.707 & 2 & 7 & 54.499 \\
2012 & 2434788 & 11 & 62 & 446.387 & 1 & 12 & 79.020 & 2 & 15 & 103.828 \\
2013 & 2452648 & 17 & 44 & 374.924 & 2 & 32 & 209.339 & 2 & 9 & 69.384 \\
2014 & 2470640 & 25 & 69 & 577.128 & 4 & 27 & 194.759 & 2 & 7 & 59.254 \\
2015 & 2488764 & 18 & 59 & 479.221 & 6 & 48 & 334.060 & 14 & 14 & 179.393 \\
2016 & 2507020 & 27 & 84 & 695.833 & 15 & 33 & 298.877 & 3 & 12 & 91.584 \\
2017 & 2525411 & 24 & 123 & 925.959 & 13 & 36 & 308.875 & 5 & 28 & 206.262 \\
2018 & 2543936 & 33 & 161 & 1235.422 & 22 & 60 & 519.397 & 5 & 27 & 201.415 \\
2019 & 2562598 & 49 & 194 & 1555.598 & 15 & 51 & 421.839 & 5 & 18 & 150.445 \\
2020 & 2581396 & 64 & 205 & 1733.626 & 17 & 61 & 501.495 & 11 & 19 & 193.728 \\
\hline
\end{tabular}

Projection of inflow data (purchases) are needed to project waste generation projections above 2020. The purchase data projected is obtained from the logarithmic regression equation shown in Fig. 4. The equation of the logarithmic regression results is useful to extrapolating inflow data obtained from the survey. The equation below is a logarithmic equation for the purchase of mobile phones, laptops, and televisions.

- Mobile phones inflow $=27.766 \ln (x)-211.088$

- Laptops inflow $=10687 \ln (x)-81243$

- Televisions inflow $=6418 \ln (x)-48776$

- The e-product purchase data will be obtained by substituting the year inflow data needed into the equation above.

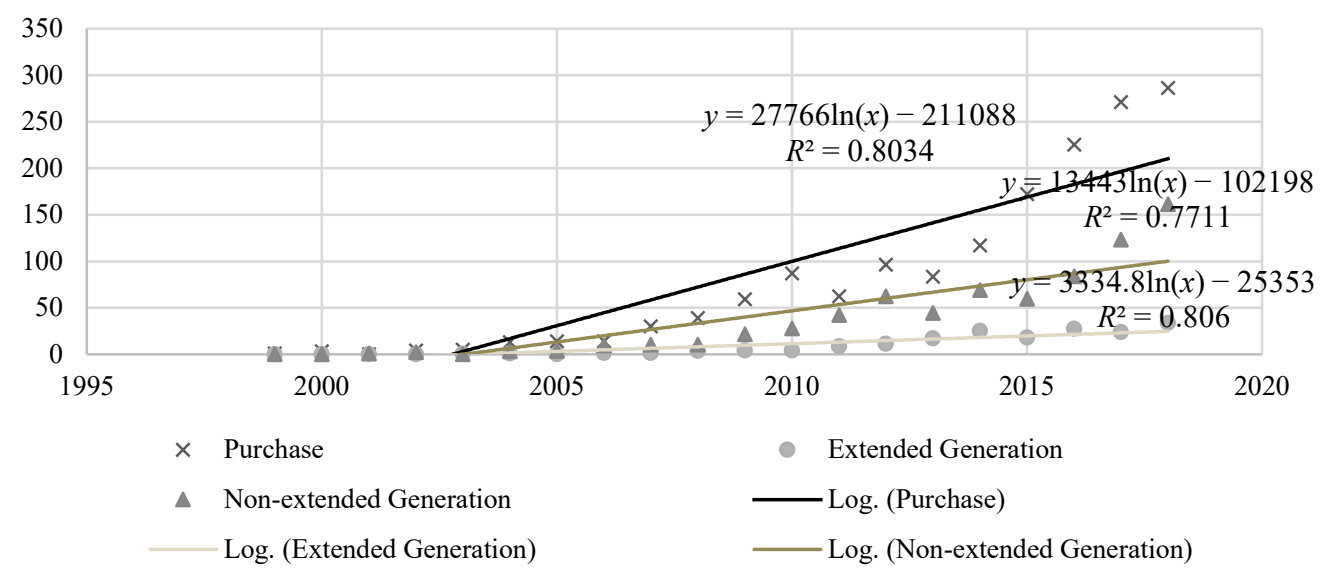

(a) 


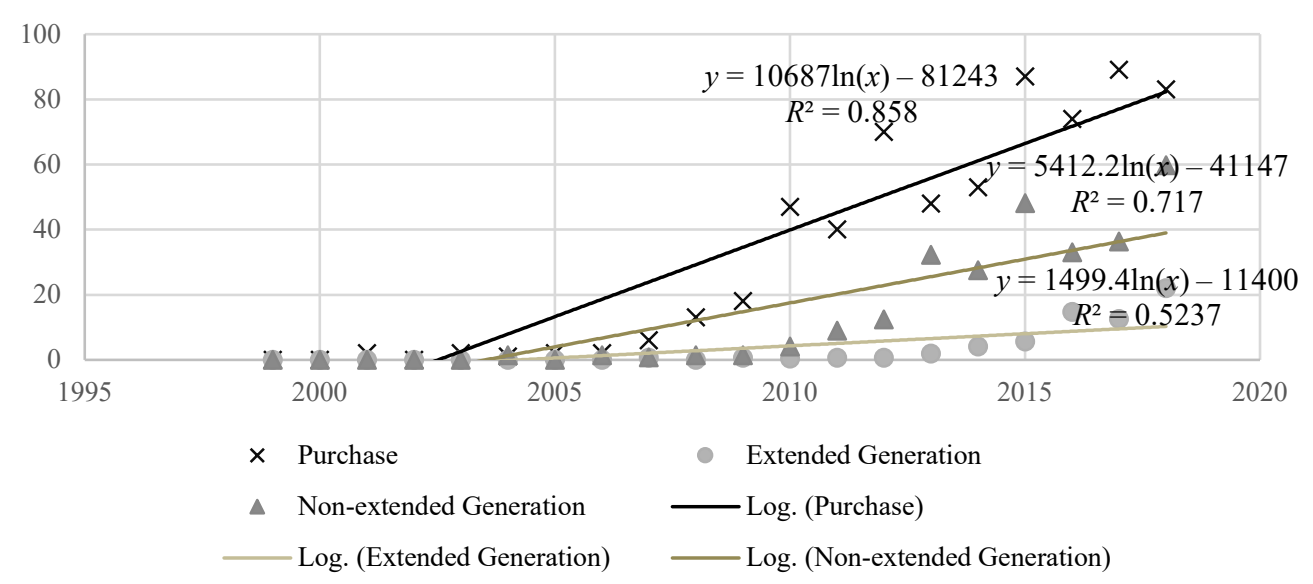

(b)

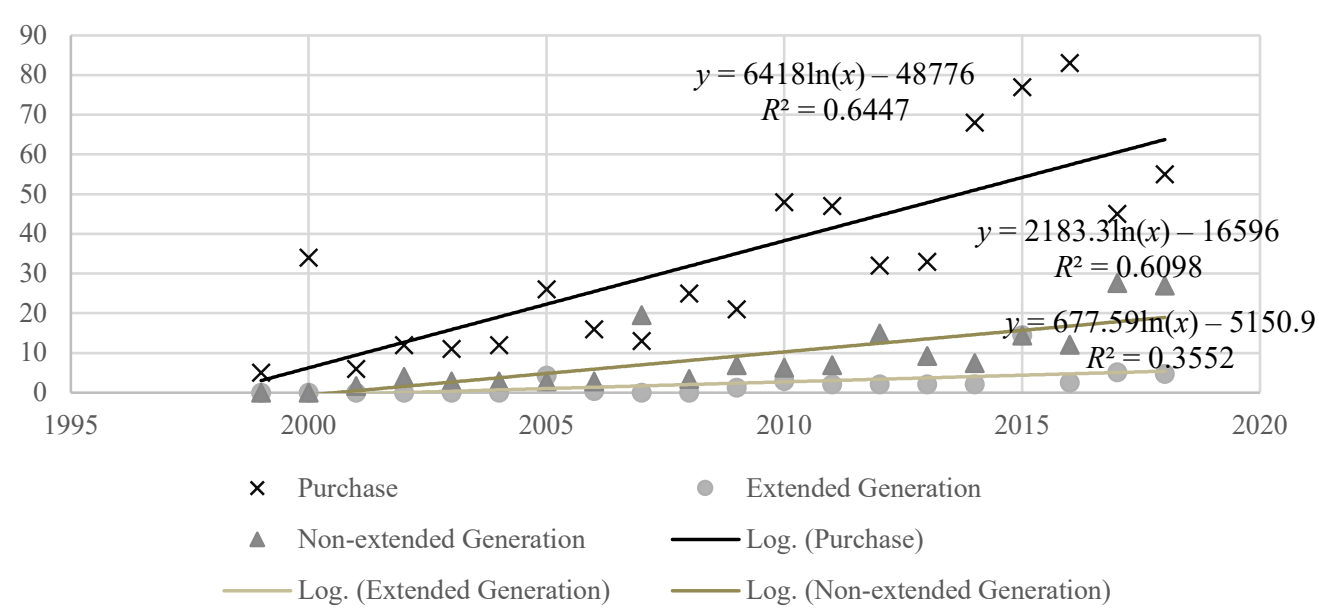

(c)

Fig. 4. Logarithmic Regression Chart of Purchase Data: a) mobile phones; b) laptops; c) televisions.

\section{Discussion}

In 2020, mobile phones, laptops, and televisions waste that will be generated in Bandung is 0.61 tons/day, 8.66 tons/day, and 3.16 tons/day and accumulated around 12.43 tons/day. WEEE generated in Bandung has a trend that continues to increase along with the increasing of Bandung citizens' buying power for electronic goods and the increasing need for electronic products such as communication and information devices. Besides, this is also influenced by the age of use and the increasing diversity of electronic products used [8].

In an e-product unit consists of various components. The presence of elements such as lead, mercury, arsenic, cadmium, selenium, hexavalent chromium and flame retardants in electronic waste and its components beyond threshold levels make it dangerous in the environment [9]. WEEE management must be carried out properly and following existing regulations so it is not caused impacts that can endanger health and the environment. Also, 
WEEE can be reused because it contains materials that have an economic value such as eplastic, glass, iron, aluminium, copper, precious metals such as silver, gold, etc. [10]. Metal components can be processed into metal ingots, e-plastic into pellets, glass into cullet glass which can be a raw material for the manufacturing industry. The utilization of metals from WEEE can be associated with urban mining. In comparison to traditional mining, WEEE or urban mining can be considered as a sustainable poly-metallic secondary resource. They are generally composed of base metals and rare/noble metals with great economic value in up to 50 times higher concentrations than natural ore mines [11], [12].

To implement WEEE formally recycling in Bandung, systematic sorting, collection and transportation of electronic waste is required to the recycling facility. There is also a need for regulations governing WEEE management systems to reduce the amount of untreated, wasted WEEE, and increase the amount of WEEE that can be recycled. WEEE recycling activities must be regulated with detailed provisions so it does not endanger human health and the environment. In addition to problems related to regulation, community participation, and operations, there are other problems, namely the amount of investment, operational costs, and land requirements. WEEE management requires a dropbox facility that is separate from other waste, special hazardous waste transport vehicles, and recycling facilities so that no small cost is needed. Then the land is needed to build drop box facilities, and recycling facilities that are following environmental and social conditions.

The electronic waste collection system is the first step closest to the source. Electronic waste collection system can be done by procuring dropbox facilities. The concept of dropbox operations is like Waste Banks where a collection system is collectively, and the community that distributes mobile phones, laptops, and/or television waste will get economic benefits from saving waste. The economic benefit of channeling waste from mobile phones, laptops and televisions is an effort to increase the enthusiasm of the community to channel their waste to recycling facilities. Each dropbox is managed by one officer who carries out the weighing of the waste that is distributed, administration of the community's waste savings book, and finance.

Electronic waste collection systems with drop boxes can be developed to support the implementation of Extended Producer Responsibility (EPR). According to the Regulation of the Minister of Environment of the Republic of Indonesia Number 13 of 2012 concerning Guidelines for the Implementation of Reduce, Reuse, and Recycle through Waste Banks, EPR is a strategy designed to integrate environmental costs into the entire production process of an item until the product cannot be used anymore so environmental costs become part of the market price component of the product. The EPR mechanism that is commonly used is through product recall and / or packaging that has expired (take-back systems). Through this scheme, producers (in this case including factories, importers, distributors, and retailers) who are subject to EPR provisions are required to withdraw products and/or packaging that have expired (post-consumer) from the public. The producers have a role to ensure that the waste processing costs incurred by consumers when buying their products are used for processing waste from the products and packaging. The waste treatment can be carried out by the producer if it has a waste processing facility and permit or can use a licensed third party processing service. Meanwhile, the community is obliged to sort, collect and hand over their mobile phones, laptop, and television waste. For producers who cannot, and do not have permission to use their mobile phones, laptop, and / or television waste, can submit these wastes to the designed recycling facility. 


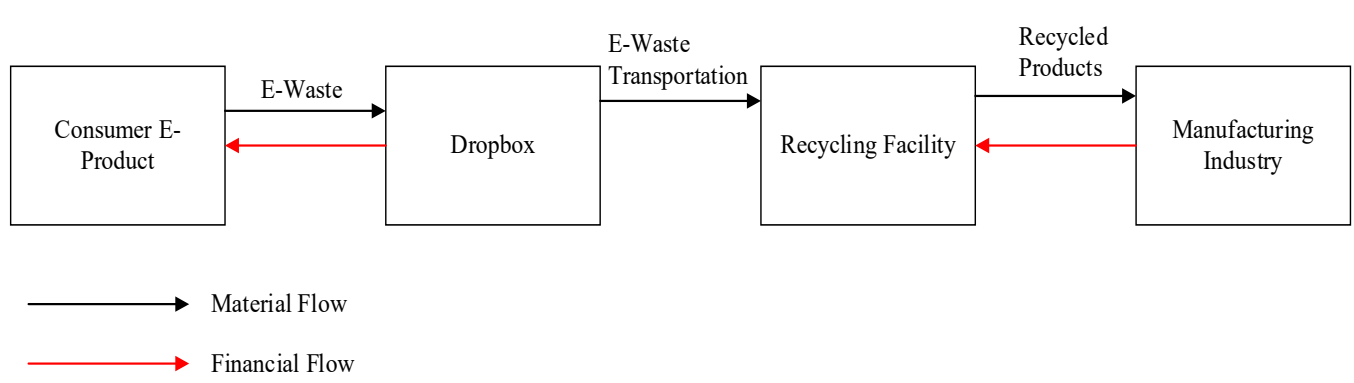

Fig. 5. Material Flow and Financial Flow without EPR.

The recycling of WEEE without EPR begins with the distribution of waste from consumers of e-products in the city of Bandung to the communal container, the dropbox, and the waste supplier will benefit in the form of money. Waste in the dropbox will be transported to the recycling facility. Products resulting from recycling activities can be sold to the manufacturing industry for use as a substitute for raw materials. The sale of recycled products is the main income of the manager of the recycling facility to cover the operational costs of managing mobile, laptop and television waste in the city of Bandung, and investment costs.

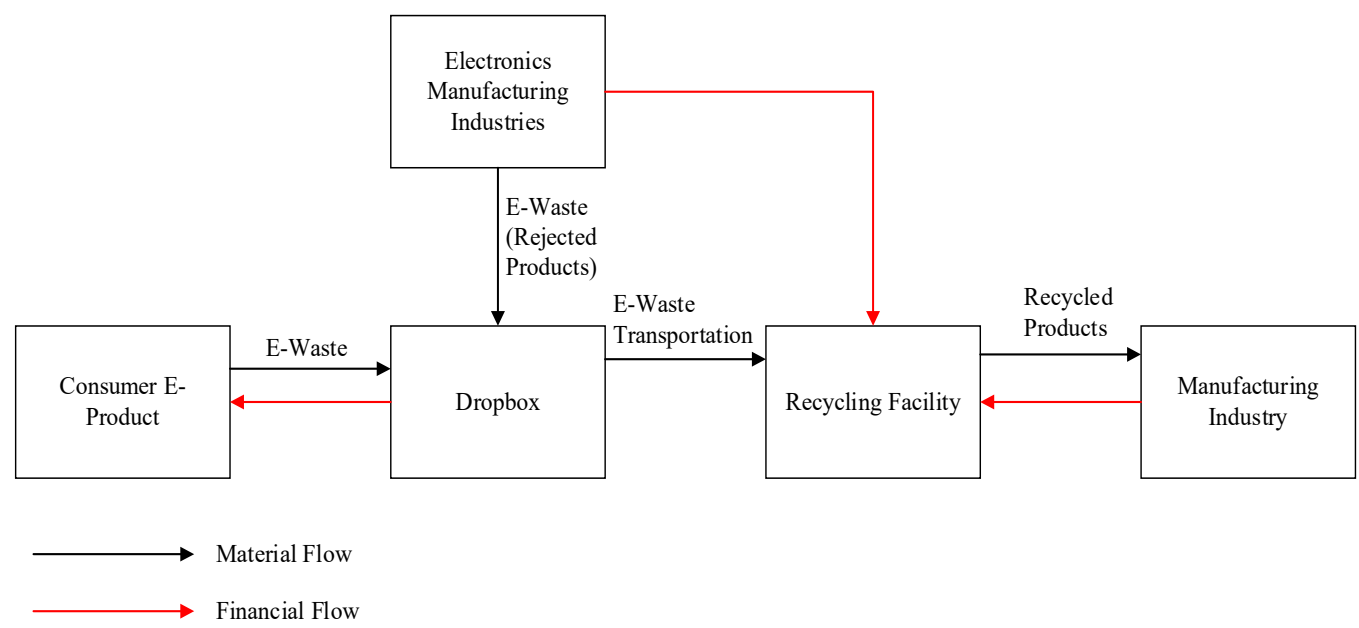

Fig. 6. Material Flow and Financial Flow with EPR.

The recycling activities of WEEE with EPR are not much different than without EPR. Electronics manufacturing industries that cannot process, and/or recycle the waste from the products they produced, they can collaborate with the manager of the recycling facility at the rate of recycling activities agreed by both parties. The waste from consumers will be channelled to the communal container (dropbox) and the waste supplier will benefit in the form of money and will be recorded what products are distributed, and the quantity. Waste in the dropbox will be transported to the recycling facility. Products resulting from recycling activities can be sold to the manufacturing industry for use as a substitute for raw materials. Sales of these recycled products, and tariffs for these recycling activities, are revenue from the manager of the recycling facility to cover the operational costs of managing WEEE and investment costs. Also, the role of the Government is needed to make regulations that govern in detail the application of EPR in WEEE management. 


\section{Conclusion}

The projection of mobile phones, laptops and televisions waste generation that will be generated in Bandung City is 0.61 tons day, 8.66 tons/day, and 3.16tons/day and accumulated around 12.43 tons/day. WEEE generated in Bandung has a trend that continues to increase along with the increasing purchasing power of the people of Bandung for electronic goods and the increasing need for electronic products such as communication and information devices. At present there is no specific and systematic management of WEEE in Bandung City. The WEEE has the potential to be recycled because electronic waste consists of components that have economic value. However, WEEE management activities must be regulated in special regulations because WEEE contains dangerous and toxic components. To formally implement WEEE recycling in Bandung, systematic sorting, collection and transportation of WEEE is required to the recycling facility.

WEEE collection system can be done with a dropbox as a communal container. The concept of waste collection is like the Waste Banks where the people who distribute their WEEE will get economic benefits. This will increase the enthusiasm and awareness of the public to channel their WEEE separately to the dropbox. Waste collection by dropbox can also be developed to support the implementation of EPR.

\section{REFERENCES}

[1] Government Regulations on Hazardous Waste Management, No. 101, 2014.

[2] Widyarsana I. M. W. Pengembangan Metode Proyeksi Timbulan Limbah 'E- waste' Berdasarkan Masa Pakai (Endof-life) Barang 'E-product' sebagai Dasar dalam Prediksi Material Flow Analysis (MFA). Bandung: Institute of Indonesia, 2011. (in Indonesian)

[3] Central Bureau of Statistics. Kota Bandung Dalam Angka 2018 (Bandung City in Figures 2018). Bandung: BPS Kota Bandung, 2019.

[4] Pertiwi A., Goto N. Potential E-waste Generated from Households in Indonesia using Material Flow Analysis. Journal of Material Cycles and Waste Management 2013:16(2):306-320. https://doi.org/10.1007/s10163-013-0191-0

[5] Central Bureau of Statistics. Kota Bandung Dalam Angka 2016 (Bandung City in Figures 2016). Bandung: BPS Kota Bandung, 2017.

[6] Yamane T. Statistics: An Introductory Analysis. 2nd Ed. New York: Harper and Row, 1967.

[7] Van Der Voet E. et al. Predicting future emissions based on characteristics of stocks. Ecological Economies 2002:41(2):223-234. https://doi.org/10.1016/S0921-8009(02)00028-9

[8] Dwivedy M., Mittal R. K. Estimation of future outflows of e-waste in India. Waste Manajement 2010:30(3):483-491. https://doi.org/10.1016/j.wasman.2009.09.024

[9] STeP Initiative. E-waste Prevention, Take-back System Design and Policy Approaches. Bonn: United Nations Univercity, 2009.

[10] Kementerian Perindustrian Republik Indonesia. Pedoman Pengelolaan Limbah Elektronik. Jakarta: Puslitbang Industri Hijau dan Lingkungan Hidup (Electronic Waste Management Guidelines. Jakarta: Center for Green Industry and Environment Research and Development.). Jakarta: Sekretariat Penghargaan Industri Hijau, 2015. (in Indonesian)

[11] Tay S. B., et al. Enhancing gold recovery from electronic waste via lixiviant metabolic engineering in Chromobacterium violaceum. Sci Rep. 2013:3:2236. https://doi.org/10.1038/srep02236

[12] Kaya M. Recovery of metals and nonmetals from electronic waste by physical and chemical recycling processes. Waste Management 2016:57:64-90. https://doi.org/10.1016/j.wasman.2016.08.004 